\title{
KATEGORIA CZASU W JĘZYKU PRAWNYM
}

1. Czas jest kategorią fleksyjną w sposób specyficzny wykorzystywaną w języku prawnym. Jest także jedną z charakterystycznych własności czasownika, stanowiącego część mowy zajmująca centralne miejsce w zasobie leksykalnym języka i będącą dominantą każdej wypowiedzi rozumianej jako podstawowa jednostka komunikacyjna ${ }^{1}$. Pojmowanie czasu może odnosić się również do semantycznego zakresu tego pojęcia. Badanie temporalnego aspektu języka jest przedmiotem różnych dyscyplin, głównie stylistyki i gramatyki. Inspiracje metodologiczne badań nad aspektem temporalnym języka sytuują się wokół dwóch głównych biegunów: lingwistyki strukturalnej i kognitywizmu². Określone wykorzystanie kategorii czasu pozostaje także w związku z charakterystyką społecznych wspólnot komunikacyjnych, stanowiących przedmiot zainteresowania badań socjolingwistycznych, obecnych również w teorii prawa. Zagadnienie czasu (oraz użycia czasowników) w języku prawnym stanowi przedmiot analiz dokonywanych na gruncie teorii prawa, a także językoznawstwa. Zwraca się uwagę na fakt, iż rzeczywistość stanowiącą przedmiot zainteresowania języka prawnego cechuje, odmienny od rzeczywistości obecnej w potocznym (powszechnym) doświadczeniu, sposób pojmowania temporalności ${ }^{3}$. Zadaniem niniejszego szkicu jest wskazanie możliwych płaszczyzn tematycznych i postulatów badawczych, w ramach których może być rozważana kategoria temporalności wykorzystywana $\mathrm{w}$ tekstach prawnych. Temporalizacja $\mathrm{w}$ języku prawnym jest charakterystyczna na tle rozróżnienia $\mathrm{w}$ gramatyce deiktycznych kategorii czasu. Odmienności w użyciu czasu występują też w wypowiedziach języka prawnego zawierających czasowniki performatywne. W kontekście rozróżnienia kategorii czasu aktualnego i czasu relatywnego charakterystyczne dla języka tekstów prawnych jest wykorzystywanie czasu relatywnego. O swoistości temporalnego aspektu sformułowań analizowanego języka świadczy również wykorzystanie określonych środków językowych, do których należy między innymi zawarta w wypo-

\footnotetext{
Z. Saloni, Wstęp do koniugacji polskiej, Olsztyn 2005, s. 5.

B. Witosz, Kategoria czasu w badaniach stylistycznych - uwagi teoretyczno-metodologiczne i postulaty badawcze, „Stylistyka” 2007, XVI, s. 12.

Tak np. T. Gizbert-Studnicki, Język prawny a obraz świata, (w:) Prawo w zmieniającym się społeczeństwie, red. G. Skapska, Kraków 1992, s. 149-161; E. Malinowska, Czas w tekście urzędowym, „Stylistyka” 2007, XVI, s. 331-339.
}

3 
wiedziach intencja perswazyjna nadawcy oraz hipotetyczny i potencjalny charakter sformułowań wyrażających normy prawne.

2. Charakterystyczną cechą kategorii czasu jest jego deiktyczny charakter, co oznacza, że sytuuje ona punkt w czasie, który odnosi się do opisywanych okoliczności, zdarzeń czy stanów rzeczy w stosunku do punktu w czasie, w którym wypowiedź jest formułowana, czyli pewnej aktualności ${ }^{4}$. Może to stanowić podstawę dokonywanego już w klasycznych gramatykach odróżnienia czasu przeszłego, teraźniejszego i przyszłego. W języku polskim znane są trzy główne odmiany czasu: teraźniejszy, używany do oznaczania czynności i stanów współczesnych w stosunku do momentu formułowania wypowiedzi (lub oznaczanego przez kontekst), czas przyszły, wskazujący czynności i stany, które mają nastąić w przyszłości oraz czas przeszły, oznaczający czynności i stany mające miejsce przed momentem formułowania wypowiedzi ${ }^{5}$. Kategoria czasu pozostaje także w ścisłym związku z aspektem czasownika, od którego zależy też charakterystyka paradygmatu kategorii czasu (to, czy jest on pełny czy zredukowany do np. tylko czasu przeszłego i nieprzeszłego) w określonych jego trybach (tryb dokonany lub niedokonany czasownika). Poszczególne odmiany temporalne sytuowane są w obrębie linii czasu i wskazują na niej przeszłość lub przyszłość. Jak twierdzą językoznawcy, we wszystkich wypowiedziach odnoszących się do rzeczywistości zawarte są (chociaż nie zawsze wyrażone explicite) informacje dotyczące temporalności ${ }^{6}$. Zasadniczo czas teraźniejszy definiowany jest jako moment w czasie tożsamy z momentem wytwarzania wypowiedzi, jednakże może być on wykorzystywany w różnych funkcjach. W języku występują także wypowiedzi określane jako neutralne wobec temporalności. Czas teraźniejszy nie zawsze jest ograniczony do aktualnego momentu formułowania wypowiedzi. Może być on używany także w tzw. stwierdzeniach ponadczasowych $^{7}$ (typu: Zima zaczyna się w grudniu, Księżyc świeci). Są one uniwersalne pod względem czasowości, tj. odnoszą się zarówno do aktualności, jak i przyszłości czy przeszłości, bądź są w swojej ponadczasowości „,bezczasowe” czy „pozaczasowe”. John Lyons podkreśla fakt, iż czas teraźniejszy nie jest jedynie odpowiadającym aktualności zerowym punktem na jednokierunkowej osi czasu (co umożliwiałoby dostrzeżenie rozróżnienia na czas teraźniejszy i nieteraźniejszy), jak również wskazywanie przyszłości może być osiagane bardziej za pomocą trybu (aspektu) niż czasu. Istnieją zatem dwa sposoby wykorzystywania czasu teraźniejszego w praktyce: na oznaczenie czynności (stanu) zachodzącego jednocześnie z aktem mówienia (czynność współczesna) lub takiej, która może występować zarówno w przyszłości, jak

J. Lyons, Wstęp do językoznawstwa, Warszawa 1975, s. 338.

J. Reczek, Czas, (w:) Encyklopedia języka polskiego, red. S. Urbańczyk, M. Kucała, Wrocław 1999, s. 45.

R. Grzegorczykowa, Wprowadzenie do semantyki językoznawczej, Warszawa 2001, s. 137.

J. Lyons, op. cit., s. 339. 
i przeszłości (czynność wieczysta, ponadczasowa) ${ }^{8}$. Omawiana kategoria gramatyczna może być wykorzystana również do oznaczania czynności mających miejsce w przeszłości, kiedy moment czasowy wyznaczony jest przez kontekst, jak w wypowiedzi typu Biegne wczoraj na dworzec... (tzw. praesens historicum). Jeszcze innym sposobem użycia czasu teraźniejszego jest formułowanie wypowiedzi, które w swoim odniesieniu zawierają przyszłość, jak. np. Wybieram się jutro do kina.

W języku prawnym występują wypowiedzi, które sytuowane są wśród komunikatów neutralnych w stosunku do czasu, określanych jako odnoszące się do zjawisk uniwersalnych czy ponadczasowych. Należą do nich takie użycia języka, które nie konstatują stanów rzeczy, w szczególności są to komunikaty pełniące funkcje imperatywne czy postulatywne (zalecenia, rady, postulaty, dyrektywy) ${ }^{9}$. Ze względu na dyrektywalny charakter ta kategoria wypowiedzi wykorzystywana jest w języku prawnym, co podkreślają zarówno teoretycy prawa, jak i językoznawcy. Na ponadczasowe (neutralne wobec czasu) określenia czasowników występujące w języku prawnym wskazuje Tomasz Gizbert-Studnicki, zauważając jednocześnie, iż pojawiają się one także $w$ innych niż prawne rodzajach wypowiedzi ${ }^{10}$. Mimo iż język tekstów prawnych opiera się na doświadczeniu pochodzącym z realnej rzeczywistości, jego głównym celem jest regulowanie określonych przyszłych przypadków (formułowanych hipotetycznie), mających wystapić w pewnych potencjalnych sytuacjach czy okolicznościach (wtedy, kiedy norma prawna znajdzie zastosowanie). Jak podkreśla jeden $z$ badaczy, temporalny wymiar regulacji prawnych jest charakteryzowany przy pomocy pewnej uniwersalności, niemożliwej do usytuowania w parametrach aktualności czy chronologiczności ${ }^{11}$. Zjawisko to jeden $\mathrm{z}$ francuskich naukowców nazywa „bezczasowością prawa” ${ }^{12}$. Wynika to z faktu, iż wśród dwóch sposobów ujmowania czasu: temporalizacji deiktycznej „tu i teraz” oraz temporalizacji zorientowanej ku przyszłości ${ }^{13}$, w wypowiedziach języka prawnego większe znaczenie ma druga $\mathrm{z}$ tych form. W języku posługującym się kategoryzowaniem sytuacji i adresatów w sposób abstrakcyjny i generalny wykorzystanie aspektu temporalnego jest ukierunkowane ku przyszłości. Wskazana kategoria temporalna jest wykorzystywana w wypowiedziach, które nie są związane z czasem aktualnym. W przypadku języka prawnego jest to temporalizacja dotycząca akcji pozaczasowych, uniwersalnych, odróżnianych od akcji określanych przy pomocy wyznaczników habitualnych (powtarzających się). Cechy języka norm prawnych, które są tu

8 T. Milewski, Językoznawstwo, Warszawa 1967, s. 100.

9 R. Grzegorczykowa, op. cit., s. 138. Autorka do tego typu wypowiedzi zalicza także pytania, w których czas teraźniejszy odgrywa specyficzną rolę.

10 T. Gizbert-Studnicki, Znamiona czasownikowe w kodeksie karnym. Zagadnienie czasu gramatycznego i aspektu, „Studia Prawnicze” 1982, nr 1-2, s. 106.

11 H.E.S. Mattila, Comparative Legal Linguistics, Aldershot-Burlington 2006, s. 73.

12 J.-C. Gémar, Les fondements du langage du droit comme langue de spécialité. Du sens st de la forme du texte juridique, "Revue générale de droit, droit (1990)", 1994, cyt. za: H.E.F. Mattila, op. cit., s. 73.

13 M.T. Lizisowa, Komunikowanie przekazu w modelach stosunków prawnych (na przykładzie „Kodeksu pracy”), „Stylistyka” 2007, XVI, s. 348. 
szczególnie istotne to: abstrakcyjny (oraz generalny) charakter sformułowań, potencjalność sytuacji i okoliczności, których ten język dotyczy, funkcja performatywna wypowiedzi oraz wpisana w treść komunikatów (aktów mowy) intencja illokucyjna nadawcy. Odmienność kategorii temporalności dotycząca tzw. bezczasowości pozostaje w ścisłym związku z pełnioną przez wypowiedzi funkcją performatywną oraz modyfikacjami funkcji czasu. Jak stwierdza Renata Grzegorczykowa, mogą one polegać na wykorzystywaniu czasu teraźniejszego używanego na oznaczanie czasu postulowanego, bądź też na użyciu czasu teraźniejszego na oznaczanie czasu niezaszłego (kontrfaktycznego) ${ }^{14}$.

W języku prawnym występują przykłady wypowiedzi formułowanych w czasie teraźniejszym wykorzystywanym nie w funkcji relacjonowania aktualnego stanu rzeczy, lecz w celu wyrażenia pewnego postulatu. Jednocześnie obecne są także wypowiedzi o funkcji performatywnej neutralne w stosunku do czasu (bezczasowe). Egzemplifikacją pierwszego rodzaju sformułowań są wypowiedzi typu: Nie można czynić ze swego prawa użytku, który byłby sprzeczny ze spoleczno-gospodarczym przeznaczeniem tego prawa lub z zasadami wspótżycia społecznego..., natomiast drugi z wskazanych przypadków obrazuje zdanie: Ciężar udowodnienia faktu spoczywa na osobie, która z faktu tego wywodzi skutki prawne. Ostatnie zaliczyć można do komunikatów posiadających tzw. predykat pozaczasowy, w odróżnieniu od wypowiedzi zawierających predykat ograniczony temporalnie, występujących w języku tekstów prawnych (Każdy człowiek od chwili urodzenia ma zdolność praw$n q)$. Jeszcze innym rodzajem odmienności w zakresie używania kategorii czasu są wypowiedzi warunkowe, zarówno te dotyczące pozaczasowości, jak i przyszłości, o których pisze wspomniana autorka ${ }^{15}$. W języku prawnym występują przykłady wypowiedzi warunkowych pierwszego (Kto pozbawia czlowieka wolności, podlega karze pozbawienia wolności od 6 miesięcy do lat 5) i drugiego rodzaju (Jeżeli ktoś pozostaje w zwiqzku matżenskim, to nie powinien zawierać powtórnie zwiqzku matżeńskiego, badź zostanie mu wymierzona kara pozbawienia wolności od 6 miesięcy do lat 5).

W języku prawnym w sposób specyficzny wykorzystywany jest czas przyszły. Znamienne jest, iż czas przyszły używany w języku powszechnej komunikacji pozwala na modyfikacje określenia momentu w przyszłości, do którego zdanie się odnosi (wypowiedź Jutro będę w Warszawie można rozumieć w jej wersjach szczegółowych jako: jutro rano, już jutro, jutro tzn. za kilka godzin, dopiero jutro itd.). Wypowiedź wykorzystująca czas przyszły sformułowana w języku prawnym cechuje się brakiem możliwości wystąpienia modyfikacji dokonywanej ze względu na czynnik bliskości czy odległości wskazywanego momentu w czasie. Wypowiedź

14 R. Grzegorczykowa, op. cit., s. 179.

15 Ibidem, s. 141-143. 
Właściwy minister wyda rozporzqdzenie oznacza: ma kompetencje do powzięcia odpowiedniej czynności konwencjonalnej (może tego dokonać, wskazany podmiot w przyszłości tego dokona). Dominacja czasu przyszłego lub teraźniejszego używanego w funkcji czasu przyszłego uzasadniona jest potencjalnością sytuacji, do których odnoszą się normy prawne ${ }^{16}$.

W tekstach prawnych obecne są także pewne swoiste sposoby odnoszenia się do przeszłości ujmowanej w powiązaniu z sytuacjami przyszłymi. Mamy z nią do czynienia na przykład w sytuacji derogowania przepisów dotychczas obowiązujących (ergo w przeszłości) przez ich uchylenie wraz z wejściem w życie nowych (tych, które obowiązywać będą w przyszłości). Dotychczas istniejące regulacje prawne zostają zastapione nowymi, stany przeszłe zostają zastapione stanami przyszłymi. Nowy akt prawny ,...nie zdaje sprawy z tych stosunków prawnych, które dotychczas istniały. Uchyla (...) te stosunki i zastępuje je nowymi, ustanawiając dla obywateli nowe uprawnienia i obowiązki" ${ }^{17}$.

3. W języku prawnym, jak w innych rodzajach użycia języka, do części mowy o najbardziej istotnym znaczeniu należą czasowniki. Jednym z mechanizmów wywierania wpływu na adresatów i wywoływania zmian w rzeczywistości jest występowanie w wypowiedziach języka prawodawcy czasowników performatywnych, które służą wyrażaniu intencji perswazyjnej i ukierunkowaniu użycia języka na wywołanie zmian. W języku prawnym czasowniki wykorzystywane są w celu denotowania określonych sposobów postępowania wskazywanych przez normy prawne, między innymi w wypowiedziach performatywnych. Przede wszystkim są to predykaty występujące $\mathrm{w}$ formie osobowej, ale także niektóre rzeczowniki odczasownikowe oraz imiesłowy przysłówkowe współczesne ${ }^{18}$. W wykorzystywaniu tej części mowy priorytetowe są funkcje związane $\mathrm{z}$ dyrektywnym poziomem tekstu prawnego, mającym pierwszoplanowe znaczenie (przed jego deskryptywnym poziomem $)^{19}$. Istnieją dwa sposoby używania w wypowiedziach czasownika performatywnego: w tzw. wypowiedziach skierowanych (adresowanych do kogośs ${ }^{20}$ występuje on w formie osobowej (zazwyczaj w pierwszej osobie), w wypowiedziach nieskierowanych (dla kogoś) pojawia się forma bezosobowa. Akty mowy zawierające ładunek performatywny mogą mieć różną postać redakcyjną 21 . W wypowie-

16 E. Malinowska, op. cit., s. 334.

17 E. Grodziński, Wypowiedzi performatywne. Z aktualnych zagadnień filozofii języka, Wrocław-Warszawa 1980, s. 14.

T. Gizbert-Studnicki, Znamiona czasownikowe..., s. 101-102.

M. Zieliński, Wykładnia prawa. Zasady, reguły, wskazówki, Warszawa 2002, s. 154.

Wyróżnienia wypowiedzi skierowanych i nieskierowanych, do których zaliczane są wypowiedzi języka prawnego, dokonuje T. Gizbert-Studnicki, Język prawny z perspektywy socjolingwistycznej, Kraków 1986.

21 John L. Austin wyodrębnił dwie kategorie performatywnych aktów mowy: zawierające czasownik performatywny eksplicytne akty mowy (tzw. performatywy wyraźne) oraz niezawierające czasownika performatywnego wyrażenia prymarne (implicytne). J.L. Austin określa niniejszym terminem wypowiedzi zawierające określony czasownik, ale także posługuje się nim na oznaczenie samego czasownika o cechach performatywnych. Performatywy 
dziach służących formułowaniu norm postępowania nadawca tekstu prawnego posiada intencję perswazyjną, jednak nie zawsze występuje w konstrukcji wypowiedzi czasownik performatywny. Mówi się wówczas o tzw. wypowiedziach implicytnie performatywnych czy prymarnych. Dyrektywny (performatywny) charakter takich aktów mowy wynikać może z komunikacyjnego kontekstu użycia języka. O powinnościowym celu wypowiedzi formułowanych przez prawodawcę przesądza również sama struktura i systematyzacja formalnej strony wypowiedzi, wyrażona w odpowiedniej budowie tekstu prawnego i sformalizowanej postaci aktów normatywnych. Forma wypowiedzi performatywnych w języku prawnym może być zróżnicowana. Omawiane akty językowe ukierunkowane na wpływanie na zachowania odbiorcy oraz wywoływanie zmian w rzeczywistości mogą być sformułowane w formie rozkazującej, ale także w postaci konstrukcji gramatycznej relacjonującej pewien stan rzeczy, dającej się wyrazić w postaci zakazu lub nakazu. W języku prawnym występują zarówno wypowiedzi performatywne eksplicytne, jak i prymarne ${ }^{22}$. Wypowiedzi performatywne określane jako implicytne mają postać konstrukcji opisowej, możliwej do przeformułowania na dyrektywę postępowania. Wykazują one pewne specyficzne cechy w zakresie użycia $\operatorname{czasu}^{23}$. Ze względu na zróżnicowanie kategorii temporalności mogą one przybierać następujące formy: wypowiedzi o konstrukcji opisowej, wyrażone w czasie teraźniejszym (Jeżeli wykonawca przejąt protokolarnie od inwestora teren budowy, ponosi on, az do chwili oddania obiektu, odpowiedzialność na zasadach ogólnych za szkody wynikłe na tym terenie) lub wypowiedzi o konstrukcji opisowej formułowane w czasie przyszłym (Szczególnq formę testamentów wojskowych określi rozporzqdzenie Ministra Obrony Narodowej wydane w porozumieniu z Ministrem Sprawiedliwości). Jak stwierdza Andrzej Malinowski, podmiot tworzący teksty prawne wykorzystuje czasowniki występujące w czasie teraźniejszym (w funkcji opisowej), przyszłym (w funkcji prognostycznej) oraz przeszłym w zależności od tego, które z elementów określenia sytuacji i okoliczności mogą być użyteczne do formułowania wypowiedzi będącej dyrektywą zawierającą czasownik w funkcji dyrektywalnej ${ }^{24}$.

4. W odróżnieniu od temporalności wskazywanej przez język ogólny, operujący przede wszystkim czasem, którego punktem odniesienia są określone przyjęte parametry (np. kalendarz), w języku prawnym występuje przede wszystkim czas re-

eksplicytne zawieraja predykat w postaci czasownika performatywnego (deontycznego) formułujący nakaz, zakaz lub dozwalający. Występuje on w pierwszej osobie liczby pojedynczej czasu teraźniejszego strony czynnej i operuje wskazywanymi w wypowiedzi modalnościami. J.L. Austin, Jak działać słowami, (w:) tenże, Mówienie i poznawanie. Rozprawy i wykłady filozoficzne, tłum. B. Chwedeńczuk, Warszawa 1993, s. 311-335. Tak A. Malinowski, Polski język prawny. Wybrane zagadnienia, Warszawa 2006, s. 113 i n. Autor przedstawia typologię wypowiedzi języka prawnego wykorzystujących czasowniki performatywne, zob. tegoż, op. cit., s. 104113

23 A. Malinowski, op. cit., s. 115.

24 Ibidem, s. 116. 
latywny. Okoliczności czy sytuacje charakteryzowane są temporalnie w odniesieniu do jakiejś innej okoliczności czy sytuacji, mającej miejsce wcześniej, później czy też równocześnie ${ }^{25}$. W sferze rzeczywistości określanej przez normy prawne teraźniejszość zazwyczaj nie występuje w znaczeniu temporalizacji deiktycznej ,tu i teraz" czy też w czasie absolutnym (zgodnym z przyjętym kalendarzowym punktem odniesienia). W języku powszechnej komunikacji spotyka się zarówno czas relatywny, jak i czas absolutny. W wypowiedziach języka prawnego dominuje czas relatywny. Wyjątek stanowić może wskazywanie momentu w czasie absolutnym, z jakim mamy do czynienia podczas określania daty wejścia w życie danego aktu normatywnego, podanej jako punkt w czasie określony w sposób jednoznaczny i odnoszący się do przyszłości. Możemy mówić o pewnej czasowej aktualności (teraźniejszości) w kontekście formułowania wypowiedzi o czasie czy trybie nabycia mocy obowiązującej przez normy prawne (na przykład terminu wejścia w życie czy użytym w czasie teraźniejszym określeniu stanu prawnego na dany aktualny moment). Czas absolutny (kalendarzowy) pojawia się w przepisach drugiego stopnia (intertemporalnych, wprowadzających, derogacyjnych), a także w odniesieniu do aktów czasowych, co do których ustawodawca wskazuje zarówno moment początkowy, jak i końcowy obowiązywania ${ }^{26}$. Sposób wykorzystywania w języku odmian czasu (absolutnego, wewnętrznego, relatywnego) ma wpływ na styl wypowiedzi oraz schematy formułowania komunikatów ${ }^{27}$. Można uznać, iż wypowiedzi używane w języku prawnym wpisują się w zakres gatunku tekstu wyrażającego określone treści wskazujące stany rzeczy, charakteryzowane przez Bożenę Żmigrodzką jako takie, które w chwili nadania jeszcze nie wystąpiły, a będą miały miejsce w przyszłości ${ }^{28}$. Komunikaty takie wskazują przyszłe stany rzeczy za pomocą tzw. zdań futurystycznych, zawierających funktor eksplikujący cel zdania, określający zdarzenie czy stan rzeczy mający nastąpić w przyszłości, zaś ich prognostycyzm ukryty jest w intencji illokucyjnej ${ }^{29}$. Dodatkową funkcją takich wypowiedzi jest określenie tego, co ma nastąpić w przyszłości. W przypadku języka prawnego nie jest to jednak typowe dla wskazanych gatunków mowy przewidywanie przyszłości, prognozowanie czy przepowiadanie.

Istotą swoistości aspektu temporalnego wypowiedzi języka prawnego jest wskazywanie stanów rzeczy i wzorów zachowania, których charakter jest abstrakcyjny i odnosi się do przyszłych możliwych sytuacji (wskazywanie pewnej potencjalności). Zabieg ten ma na celu objęcie za pomocą abstrakcyjnie i generalnie sformułowanej normy prawnej możliwie szerokiej klasy podmiotów (adresatów) i sytuacji.

T. Gizbert-Studnicki, Język prawny..., s. 157.

Zob. S. Wronkowska, M. Zieliński, Komentarz do zasad techniki prawodawczej, Warszawa 2004, s. 133-135.

B. Witosz, Kategoria czasu w badaniach stylistycznych - uwagi teoretyczno-metodologiczne i postulaty badawcze, „Stylistyka” 2007, XVI, s. 15.

B. Żmigrodzka, Gatunki tekstów odnoszących się do przyszłości, „Stylistyka” 2007, XVI, s. 531.

Ibidem, s. 533 
Wymaga to konieczności przewidywania możliwych zmian okoliczności oraz formułowania wypowiedzi odnoszących się do pewnego poziomu hipotetycznych sytuacji wskazywanych przez normy prawne ${ }^{30}$, a także przyznawania określonym podmiotom kompetencji, wyznaczenia zakresu obowiązków bądź uprawnień. Potencjalność czy ewentualna „prognostyczność” dotyczy wskazania takiego stanu rzeczy, który będzie obowiązujący po przekroczeniu cezury „wejścia w życie” danej regulacji jako odnoszący się do aktualizacji wzorów postępowania wskazanych w normie prawnej ${ }^{31}$. Znamienny dla języka prawnego brak tożsamości czasowej między aktem formułowania (tworzenia) wypowiedzi a aktem jej odbioru (implikowany przez jego funkcje) wpływa na pewną hipotetyczność wypowiedzi ${ }^{32}$. Swoistość wykorzystania kategorii temporalności w języku prawnym przejawia się w tym, iż wypowiedzi formułowane w konstrukcji teraźniejszej nie odnoszą się do aktualności, a dotyczą de facto sytuacji, które będą miały miejsce w przyszłości ${ }^{33}$. Przekonuje o tym fakt, iż jak wskazują badania nad statystykami używania określeń czasowych w szwedzkim języku prawnym, występuje jedynie od 5 do 8\% jego składników mających odpowiedniki w parametrach czasu i przestrzeni ${ }^{34}$. Ukierunkowany ku przyszłości wymiar czasowy tekstu prawnego znajduje uzasadnienie przede wszystkim w funkcji wypowiedzi, kwestiach obowiązywania norm prawnych, jak też pozycji i autorytetu nadawcy ${ }^{35}$.

5. Kształtowanie temporalności może zależeć także od użycia pewnych środków językowych ${ }^{36}$. Specyficzne wykorzystanie kategorii czasu w języku prawnym uzasadnione jest swoistymi cechami i funkcjami tego sposobu wypowiedzi. Do podmiotów formułujących teksty prawne kierowane są postulaty dążenia do precyzji, jasności, komunikatywności, realizowania wymogów dotyczących schematu budowy aktu normatywnego oraz wszelkich reguł kompozycji, sposobu używania środków językowych, formułowania definicji itp. Wskazane dyrektywy dotyczące posługiwania się językiem podczas tworzenia tekstów prawnych znalazły także odzwierciedlenie w regulacjach prawnych, przede wszystkim w Zasadach techniki prawodawczej ${ }^{37}$. Użycie czasu pełni tu także istotną rolę. Konieczność spełniania przez wypowiedzi języka prawnego postulatów jasności i komunikatywności

\footnotetext{
30 H.E.S. Mattila, op. cit., s. 73.

31 S. Wronkowska, Z. Ziembiński, Zarys teorii prawa, Poznań 2001, s. 32.

32 B. Hałas, Terminologia języka prawnego, Zielona Góra 1995, s. 41.

33 Z. Ziembiński, Teoria prawa, Warszawa-Poznań 1978, s. 23-24.

34 H.E.S. Mattila, op. cit., s. 73.

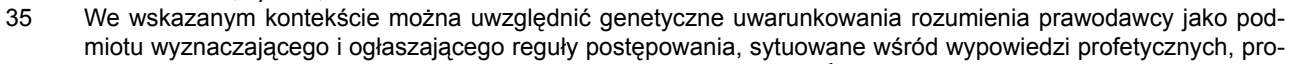
roczych, pełniących pierwotnie funkcje religijne lub ludyczne. Por. B. Żmigrodzka, op. cit., s. 536-538.

36 T. Dobrzyńska, Zatrzymać czas. O językowych i tekstowych sposobach kształtowania czasu w utworach poetyckich, „Stylistyka” 2007, XVI, s. 128.

37 Rozporządzenie Prezesa Rady Ministrów z dnia 20 czerwca 2002r. w sprawie Zasad techniki prawodawczej, Dz.U. Nr 100, poz. 908.
} 
(służących także zapewnieniu stabilności i skuteczności prawa ${ }^{38}$ ) dotyczy nie tylko sposobów wyrażania modalności normatywnych, ale też określoności czasowego wymiaru obowiązywania norm prawnych. Odzwierciedla to założenia systemowe odnoszące się zarówno do zasad konstrukcyjnych (niesprzeczność treści norm, postulat zupełności, obowiązywanie normy prawnej od momentu wejścia w życie ukierunkowane na przyszłość, zakaz retroakcji, wymóg stosowania odpowiedniego vacatio legis), jak i aksjologiczne uzasadnienie systemu prawa ${ }^{39}$. W języku prawnym determinantami wskazanego sposobu formułowania treści oraz używania kategorii czasu są przede wszystkim: potencjalność, kategoryczność i hipotetyczność sformułowań, dążenie do precyzji, a także brak kazuistyki, typowej dla określania zjawisk teraźniejszych, aktualnych.

Uzasadnienie użycia $\mathrm{w}$ wypowiedzi określonej kategorii temporalności możliwe jest dzięki wykorzystywaniu różnych wyznaczników wypowiedzi (gatunku, podmiotu, tematu, komponentu pragmatycznego) ${ }^{40}$, a także tekstowych wykładników charakterystyki temporalnej. Do istotnych środków można też zaliczyć funkcje pełnione przez wypowiedzi. Nadawca tekstu prawnego, wskazując w normach prawnych wzory postępowania, ukierunkowuje je na określone zakresy zastosowania i normowania, odnoszące się do klas potencjalnych, przyszłych sytuacji i zachowań. Wykorzystanie kategorii temporalności w języku prawnym znajduje uzasadnienie w funkcji dyrektywalnej (perswazyjnej, postulatywnej), zajmującej prymarną wśród innych pozycję. Wśród funkcji wypowiedzi języka tekstów prawnych priorytetową rolę pełni „normatywna funkcja kwalifikowania stanów rzeczy”, podczas gdy inne gatunki tekstu ukierunkowane na komunikowanie lub asercję cechują się przede wszystkim funkcją reproduktywną w stosunku do określonych fragmentów rzeczywistości ${ }^{41}$. Dominacja w języku prawnym funkcji dyrektywalnej osiagana jest między innymi za pomocą illokucyjnych aktów mowy, których cechą jest ukierunkowanie na przyszłość. Nadawca posługuje się językiem prawnym z wyraźnie zaakcentowanym celem. Chcąc skłonić odbiorcę do określonego zachowania, wykorzystuje różne (jawne lub ukryte) mechanizmy perswazji ${ }^{42}$. Formułowana z zamiarem illokucyjnym wypowiedź implikuje dwa cele użycia języka prawnego: wyrażenie normy postępowania (normy prawnej) i wywieranie wpływu na zachowania adresatów norm (działania podmiotów prawa wyznaczone przez wzory sformułowane w przepisach) oraz wywoływanie zmian w rzeczywistości pozajęzykowej (kształto-

Znajduje to odzwierciedlenie w przekonaniu, iż ,jednolitość i pewność rozumienia tekstów prawnych może odgrywać doniosłą rolę w społecznym działaniu prawa”, zob. J. Wróblewski, Zagadnienie jednolitości i pewności rozumienia tekstów prawnych, „Państwo i Prawo” 1966 nr 3, s. 540.

9 Na temat skuteczności oddziaływań prawnych oraz wymogów jasności prawa zob. także: S. Wronkowska, Z. Ziembiński, Zarys teorii prawa, Poznań 2001, s. 197 i n.

B. Witosz, op. cit., s. 11.

M.T. Lizisowa, Tekst-kontekst-interpretacja. W poszukiwaniu semiotyczno-dyskursywnych wzorców konkretyzacji języka, Kraków 2006, s. 289.

$\mathrm{Na}$ ten temat zob. I. Szczepankowska, Wpływ intencji perswazyjnej nadawcy na styl dawnej i współczesnej wypowiedzi prawodawczej w języku polskim, (w:) tejże, Styl a semantyka, Białystok 2008, s. 411-426. 
wanie, modyfikacja, tworzenie, znoszenie stosunków prawnych i stanów prawnych). Sposobem na osiagnięcie zarówno konstruowania, jak i wyrażania tak określonego teleologicznego aspektu języka jest wyrażenie postulatów normatywnych za pomocą użycia określonej formy i struktury wypowiedzi, w tym także wykorzystania kategorii czasu. Na poziomie tekstu prawnego występują różne typy illokucji. Prymarna to wyrażanie dyrektyw, sekundarna to kreowanie pewnego modelu czy wizji rzeczywistości zawartych w wypowiedziach jako treści presuponowane. Istotnym wykładnikiem języka prawnego pozostającym w związku ze sposobem używania kategorii czasu jest relacja języka do rzeczywistości. Dokonane w ramach pragmatyki językowej i kognitywizmu odkrycia na temat natury języka pozwalają sądzić, iż w języku zawarty jest pewien obraz świata, który jest przez ten język konceptualizowany. Ogląd świata możliwy do zrekonstruowania na podstawie wypowiedzi języka prawnego to pewna postulowana wizja rzeczywistości, zgodna z regułami zawartymi w dyspozycjach norm prawnych konstytuujących system prawa w danym hic et nunc. Istotne znaczenie w kształtowaniu temporalności ma także niekonstatywny charakter wypowiedzi. Język prawny nie służy przekazywaniu deskrypcji referujących rzeczywistość. Odzwierciedla on pewien potencjalny model rzeczywistości, możliwy do zrekonstruowania na podstawie interpretowanej z tekstu wiedzy na temat preferencji (aksjologicznych, etycznych) prawodawcy. Celem formułowanych wypowiedzi nie jest relacjonowanie zastanego stanu świata zewnętrznego, lecz wyrażanie sugestii i postulatów dotyczących powinności, wzorów zachowania kierowanych do adresatów. Zdania te projektują pewną rzeczywistość pozostającą w stanie, jaki powinien mieć (a nie ma - jak w wypowiedziach deskryptywnych) miejsce, zgodnie z założeniami prawodawcy. Pozycja i autorytet nadawcy pozwalają na „kreowanie” rzeczywistości za pomoca języka. Ta swoista kreatywna funkcja języka sprzyja formułowaniu za pomocą tekstów prawnych pewnej wizji powinności ${ }^{43}$. Jak podkreślają teoretycy prawa, swoistość kreacyjnej roli języka prawnego w stosunku do rzeczywistości polega zarówno na tym, iż przy pomocy wypowiedzi wywoływane są zmiany, tworzone są nowe stany prawne, jak również zawarte w treści norm prawnych informacje presupozycyjne (przekazywane implicite) pozwalają na uzyskiwanie w drodze interpretacji wiedzy na temat pewnej rzeczywistości społecznej, panujących w niej przekonań, zasad i wartości ${ }^{44}$.

6. Temporalność jest kategorią w sposób specyficzny wykorzystywaną w języku prawnym. Wynika to zarówno ze swoistości temporalizacji dostrzeganej w kontekście wyróżniania deiktycznych odmian czasu, jak również ze względu na stosowanie określonych środków językowych, traktowanie wypowiedzi języka prawnego jako aktu mowy o intencji illokucyjnej, pełnienia przez wypowiedzi funkcji dy-

43 E. Malinowska, op. cit., s. 333.

44 R. Sarkowicz, J. Stelmach, Teoria prawa, Kraków 1998, s. 41-43. 
rektywalnej oraz konsekwencji wykorzystywania czasowników performatywnych. Istotną i często podkreślaną cechą jest używanie czasu teraźniejszego $\mathrm{w}$ funkcji postulowania określonych stanów rzeczy czy sytuacji mających wystąpić w przyszłości. Ważną kwestią jest zatem abstrakcyjność i generalność sformułowań używanych w języku prawnym oraz odniesienie ich do potencjalności, a także pewna hipotetyczność. Kategoria czasu wykorzystywana jest w wypowiedziach formułowanych przez ustawodawcę także w związku z wskazywaniem momentu (początkowego czy końcowego) obowiązywania norm prawnych, co występuje w treści przepisów drugiego stopnia informujących o terminie wejścia w życie lub utracie mocy obowiązującej przez wskazane przepisy bądź ich części. Interesującym proponowanym do ewentualnego rozważenia problemem mogłoby być także zagadnienie temporalności, rozważane w kontekście rozumianych jako określone punkty czasowe terminów przyjętych w prawie (np. doręczenie, przedawnienie, zwłoka), a także zagadnienie upływu czasu powodującego skutki prawne (uzyskanie pełnoletności, uznanie za zmarłego), co jednakże wykracza poza zakres niniejszego szkicu i może być proponowane do ewentualnych przyszłych rozważań.

W kontekście rozważań o temporalności w języku prawnym warto wspomnieć, iż czas w prawie nie poddaje się zjawiskom chronocentryzmu, kompresji czasu czy rosnącej szybkości przetwarzania informacji, występującym w wielu innych sferach społecznej aktywności i poziomach współczesnych dyskursów jako wszechobecne tendencje charakteryzujące ponowoczesną rzeczywistość ${ }^{45}$. Jest bardziej statycznie pojmowany niż w innych sferach, rozpięty między biegunami przeszłość - przyszłość. Charakterystycznym zjawiskiem jest różne ujmowanie i wykorzystanie czasu w różnych typach dyskursu ${ }^{46}$, odmienne nastawienie na frazy czasu, takie jak przeszłość, przyszłość, teraźniejszość oraz różne modelowanie czasu. Język powszechnej komunikacji posługuje się kategoriami przeszłość - teraźniejszość przyszłość. Język prawny zorientowany jest wokół punktów: czas nadawania (tworzenia) komunikatu - czas wejścia w życie - przyszłość (obowiązywanie). 


\title{
CATEGORY OF TIME IN THE LEGAL LANGUAGE
}

\author{
SUMMARY
}

The task of this text is to point possible thematic basis of topics, that category of temporary used in legal texts can be considered. Reality constituting the object of interest of legal language characterizes understanding temporary in the way which is contrary from reality existing in ordinary experience. Time in low is mainly used for needs of forming the legal norms referring to future situations and circumstances, in which the recipient of the rule will be existing. That is why the abstraction of legal language has an essential importance in the context of analyzing the category of time in this language. Another important characteristic feature of using category of temporary is occurrence in legal language almost only relative time. Features of situations showing in legal norms and regulations relate to the future. However they can be formulated using the present time appearing in a specific function. References to the present do not usually exist in legal texts. Absolute time referring to specific dates appears only in regulations in the context of determination of temporary range of applicable in variously describing information relating to the term of entry into force (day, month and year). Perception of legal expressions in the light of types of speech acts have just as important relations with temporal aspect. First of all the way of use the verbs and performative function of the statement are very fundamental. In this context a very essential thing is that emphasizing the fact that legal language contains illocutionary acts written in the contents of reports. Above-mentioned features determinate specific usage of category of time in legal language. 